\title{
Effect of After-Treatment of Strychnos ligustrina Extract on The Percentage of Parasitemia in Mice Infected with Plasmodium berghei
}

\author{
Umi Cahyaningsih ${ }^{1}$, Siti Sa'diah ${ }^{2}$, Wasrin Syafii ${ }^{3}$, Rita K. Sari ${ }^{3}$, Harisyah $\mathrm{M}^{3}$, and Maeda Wahyuningrum ${ }^{3}$ \\ ${ }^{1}$ Department of Animal Diseases and Veterinary Health, Faculty of Veterinary Medicine, IPB University, Bogor, Indonesia \\ ${ }^{2}$ Department of Anantomy, Physiology and Pharmacology, Faculty of Veterinary Medicine, IPB University, Bogor, Indonesia \\ ${ }^{3}$ Department of Forest Product, Faculty of Forestry, IPB University, Bogor, Indonesia
}

\begin{abstract}
Antimalarial treatment is usually given up to 4 days which reduces the number of parasitemia, but malaria can still occur. Therefore, a study to determine the percentage of parasitemia after drug administration is important. Strychnos ligustrina has been investigated in vitro to inhibit the growth of Plasmodium berghei and reduced the number of parasitemia during 4 days of treatment. The purpose of this study was to determine the percentage of parasitemia in mice infected with $P$. berghei after 4 day treatments with $S$. ligustrina extract. S. ligustrina was extracted by maceration method using Ethanol 25\%, 50\%, and 75\% (E25, E50, E75, respectively), and Aquades (EA). This study used 91 male mice divided into 5 groups: E25, E50, E70, EA, each extract consisted of 3 doses $(200,400$ and $800 \mathrm{mg} / \mathrm{kg}$ BW) and Drug Control (DC). For Drug Control (DC) was using a combination of Dihy-droartemisin dose $25 \mathrm{mg} / \mathrm{kg} \mathrm{BW}$ and piperaquine phosphate dose $197 \mathrm{mg} / \mathrm{kg} \mathrm{BW}$. Mice infected with 1x 10 $\mathrm{P}$. berghei intraperitoneally. Blood samples were taken on day 5 after treatment with S. ligustrina extract for 8 days (days 1-8 after treatment). Preparation of blood smear was stained with Giemsa to calculate the percentage of parasitemia by counting the number of infected erythrocytes divided by 500 erythrocytes and multiplied by $100 \%$. The percentages of parasitemia day 7 with 3 kinds of doses of $200,400,800 \mathrm{mg} / \mathrm{kg}$ body weight in $\mathrm{E} 25$ (11,54\%, $2.60 \%$ and $11.54 \%$, respectively), in E50 (3.44\%, 0\%, 3.81\%, respectively), in E75 $(19.25 \%, 0.73 \%, 9.75 \%$, respectively), in EA $(0.77 \%, 4.48 \%, 8.67 \%$, respectively) and in DC $2.10 \%$. At the stage of schizogony, which is one of the life cycles of malaria found in the liver, this parasite is not visible in the blood circulation. The results showed that $P$. berghei was still found in the blood of mice after administration of $S$. ligustrina extracts up to 4 days in all treatments with different percentages of parasitemia. Based on these results it is recommended that the administration of drugs with S. ligustrina extract as antimalarial drugs for more than 4 days.
\end{abstract}

Keywords: Strychnos ligustrina, Plasmodium berghei.

\section{Introduction}

Malaria is a disease caused by protozoa, the genus Plasmodium and to treat malaria using anti-malarial drugs [1]. Chloroquine is widely used as an antimalarial drug but there is a problem of Plasmodium resistance to the drug, so in 2004 the Republic of Ministry of Health determined the change of drugs from chloroquine to Artemisinin-based Combination Therapy (ACT) [2]. Some research shows there is a failure of artemisinin therapy at the Thai-Cambodja border. It is possible that Plasmodium begins to develop resistance to the drug [3]. Because it is necessary to look for other plants as antimalaria drugs. This study uses $S$. ligustrina as an antimalarial drug.

The use of S. ligustrina wood as an antimalarial in the form of aqueous extract in vitro can inhibit the growth of parasites by $100 \%$ [4]. In addition, in vitro studies of $S$. ligustrina ethanol extract also showed inhibition of Plasmodium growth [5].

In this study using, $P$. berghei is a species of Plasmodium that infects the blood cells of mice because it is used as a model to study the pathogenesis of malaria [6].

The use of antimalarial drug ACT artesunateamodiakuin was carried out for three days [7] as well as the administration of dihydroartemisinin-piperaquine (DHP) taken once a day for three days [8]. During the treatment, a period can reduce the percentage of parasitemia but malaria recurrence can still occur. Because it is necessary to do research to determine the percentage of parasitemia after treatment.

The purpose of this study was to determine the percentage of parasitemia after treatment with $S$. ligustrina extract in mice infected with P. berghei.

Corresponding author: umicahyaningsih@yahoo.co.id 


\section{Materials and Methods}

\subsection{Preparation of extract}

Strychnos ligustrina wood is dried, ground and filtered with a size of 40-60 mesh so that it becomes powder. Then the wood powder was extracted by the maceration method using 25\% Ethanol (E25), 50\% Ethanol (E 50), 75\% Ethanol (E75) and Aquades (EA). The extraction process is carried out for 24 hours. The extracted filtrate was concentrated with a rotary evaporator and then used to test for $P$. berghei in mice.

\subsection{Treatment of mice}

The mice used were DDY strain male mice with a bodyweight of 20-25 g aged 1.5 - 2.5 months. Before the mice were infected, they were acclimatized for seven days and given worm medicine, antibiotics, and anti protozoa. This study used four kinds of extracts (E 25, E50, E70, EA), each extract consisting of three doses (200, 400 and $800 \mathrm{mg} / \mathrm{kg} \mathrm{BW}$ ) and Drug Control (KO), each treatment consisted of seven mice. For Drug Control (DC) using a combination of Dihydroartemisin dose of $25 \mathrm{mg} / \mathrm{kg} \mathrm{BW}$ and piperaquine phosphate dose of $197 \mathrm{mg} / \mathrm{kg} \mathrm{BW}$. Mice infected with 1x106 P.berghei intraperitoneally.

The extract and drug are given orally once a day, on the third day after $P$. berghei infection because mice have shown positive for $P$. berghei infection as a result of blood examination. The duration of administration of the extract and drug is four days (on the third to sixth day after infection).

\subsection{Blood collection and blood smear}

Blood collection is carried out for eight days, since the last administration of extracts and drugs (the first day to the eighth day after the last administration of extracts and drugs).

Blood collection through the vein coccygeal at the tip of the tail of the mice, then blood staining is done by Giemsa staining to calculate the percentage of parasitemia by counting the number of parasites in erythrocytes divided by 500 erythrocytes and then multiplying $100 \%$.

\subsection{Data analysis}

Data on the average percentage of parasitemia was processed by ANOVA (Analysis of Variants) test. The difference in extract treatment was tested with Duncan at a $5 \%$ level.

\section{Results and Discussion}

In general, there was an increase in the percentage of parasitemia from day one to eight after administration of extracts and drugs for four days except for the treatment of E25D400, E50D400, E75D400 and EAD200, the percentage of parasitemia was lower than Drug Control. On the eighth day after treatment, the percentage of parasitemia with three types of doses of $200,400,800 \mathrm{mg}$ / $\mathrm{kg}$ body weight at E25 (11.54\%, 2.60\% and $11.54 \%$, respectively), at E50 (respectively $3.44 \%, 0 \%, 3.81 \%$ ), in E75 $(19.25 \%, 0.73 \%, 9.75 \%$, respectively), in EA $(0.77 \%$, $4.48 \%, 11.55 \%$, respectively) and in DC $2.10 \%$ (Table 1).

Table. 1 The average percentage of mice parasitemia infected with P. berghei after administration of S. ligustrina extract and drugs.

\begin{tabular}{|c|c|c|c|c|c|c|c|c|}
\hline \multirow{2}{*}{ Treatment } & \multicolumn{8}{|c|}{ Day observation (after treatment) } \\
\hline & 1 & 2 & 3 & 4 & 5 & 6 & 7 & 8 \\
\hline E25D200 & $6,40 \pm 6,01^{\mathrm{bc}}$ & $6,28 \pm 6.03^{\mathrm{bc}}$ & $4,40 \pm 4,10^{\mathrm{ab}}$ & $4,21 \pm 3,87^{\text {abcd }}$ & $8,47 \pm 11,43^{\mathrm{a}}$ & $8,54 \pm 9,99^{\mathrm{ab}}$ & $9,98 \pm 7,39^{\mathrm{ab}}$ & $11,54 \pm 8,52^{\mathrm{ab}}$ \\
\hline E25D400 & $0,06 \pm 0,09^{\mathrm{a}}$ & $1,61 \pm 3,14^{\mathrm{ab}}$ & $0 \pm 0^{\mathrm{a}}$ & $0 \pm 0^{\mathrm{a}}$ & $0 \pm 0^{\mathrm{a}}$ & $0 \pm 0^{\mathrm{a}}$ & $1,24 \pm 1,18^{\mathrm{a}}$ & $2,60 \pm 1,19^{\mathrm{a}}$ \\
\hline E25D800 & $5,61 \pm 1,06^{\mathrm{bc}}$ & $6,21 \pm 1,39^{\mathrm{bc}}$ & $4,47 \pm 1,70^{\mathrm{ab}}$ & $7,29 \pm 4,49^{\mathrm{bcd}}$ & $10,32 \pm 6,86^{\mathrm{a}}$ & $9,31 \pm 4,93^{\text {ab }}$ & $17,59 \pm 10,84^{\mathrm{bc}}$ & $11,54 \pm 8,52^{\mathrm{ab}}$ \\
\hline E50D200 & $2,82 \pm 4,44^{\mathrm{abc}}$ & $1,50 \pm 3,34^{\mathrm{ab}}$ & $1,22 \pm 2,72^{\mathrm{a}}$ & $2,68 \pm 5,99^{\mathrm{abcd}}$ & $3,56 \pm 7,95^{\mathrm{a}}$ & $3,39 \pm 7,58^{\mathrm{ab}}$ & $1,99 \pm 4,44^{\mathrm{a}}$ & $3,44 \pm 7,69^{\mathrm{a}}$ \\
\hline E50D400 & $3,08 \pm 3,75^{\mathrm{abc}}$ & $3,54 \pm 6,05^{\mathrm{abc}}$ & $0,00 \pm 0^{\mathrm{a}}$ & $0,00 \pm 0^{\mathrm{a}}$ & $0,00 \pm 0^{\mathrm{a}}$ & $0,00 \pm 0^{\mathrm{a}}$ & $0,00 \pm 0^{\mathrm{a}}$ & $0,00 \pm 0^{\mathrm{a}}$ \\
\hline E50D800 & $2,33 \pm 5,21^{\mathrm{ab}}$ & $2,21 \pm 4,94^{\mathrm{abc}}$ & $5,10 \pm 7,21^{\mathrm{ab}}$ & $1,19 \pm 2,65^{\mathrm{ab}}$ & $1,49 \pm 3,34^{\mathrm{a}}$ & $2,53 \pm 4,67^{\mathrm{ab}}$ & $5,18 \pm 8,37^{\mathrm{a}}$ & $3,81 \pm 6,05^{\mathrm{a}}$ \\
\hline E75D200 & $4,90 \pm 2,58^{\mathrm{abc}}$ & $4,14 \pm 2,79^{a b c}$ & $3,56 \pm 3,76^{\mathrm{ab}}$ & $8,86 \pm 5,70^{\mathrm{cd}}$ & $9,94 \pm 10,33^{\mathrm{a}}$ & $9,63 \pm 11,32^{\mathrm{ab}}$ & $23,29 \pm 29,32^{\mathrm{c}}$ & $19,25 \pm 24,17^{\mathrm{ab}}$ \\
\hline E75D400 & $2,59 \pm 3,65^{\mathrm{abc}}$ & $2,07 \pm 1,01^{\mathrm{abc}}$ & $2,24 \pm 1,16^{\mathrm{ab}}$ & $1,03 \pm 0,38^{\mathrm{ab}}$ & $1,45 \pm 0,50^{\mathrm{a}}$ & $0,72 \pm 0,51^{\mathrm{a}}$ & $0,75 \pm 0,36^{\mathrm{a}}$ & $0,73 \pm 0,65^{\mathrm{a}}$ \\
\hline E75D800 & $14,35 \pm 4,99^{\mathrm{abc}}$ & $0 \pm 0^{\mathrm{a}}$ & $6,29 \pm 6,89^{\mathrm{ab}}$ & $1,73 \pm 3,46^{\mathrm{ab}}$ & $2,60 \pm 4,23^{\mathrm{a}}$ & $1,11 \pm 1,93^{\mathrm{a}}$ & $6,48 \pm 11,22^{\mathrm{ab}}$ & $9,75 \pm 13,78^{\mathrm{ab}}$ \\
\hline EAD200 & $0,74 \pm 1,54^{\mathrm{abc}}$ & $1,48 \pm 3,11^{\mathrm{ab}}$ & $0 \pm 0^{\mathrm{a}}$ & $0,09 \pm 0,17^{\mathrm{a}}$ & $0,11 \pm 0,15^{\mathrm{a}}$ & $0,35 \pm 0,23^{\mathrm{a}}$ & $0,62 \pm 0,03^{\mathrm{a}}$ & $0,77 \pm 0,75^{\mathrm{a}}$ \\
\hline EAD400 & $0,04 \pm 0,05^{\mathrm{a}}$ & $1,27 \pm 2,10^{\mathrm{ab}}$ & $3,93 \pm 4,52^{\mathrm{ab}}$ & $6,36 \pm 8,36^{\mathrm{abcd}}$ & $6,63 \pm 9,35^{\mathrm{a}}$ & $5,03 \pm 7,79^{\mathrm{ab}}$ & $3,63^{\mathrm{a}}$ & $4,48 \pm 5,77^{\mathrm{a}}$ \\
\hline EAD800 & $3,05 \pm 3,92^{\mathrm{abc}}$ & $4,23 \pm 5,01^{\mathrm{abc}}$ & $3,95 \pm 6,05^{\mathrm{ab}}$ & $6,06 \pm 8,51^{\mathrm{ab}}$ & $9,67 \pm 11,29^{\mathrm{a}}$ & $12,78 \pm 17,82^{\mathrm{ab}}$ & $7,72 \pm 9,18^{\mathrm{ab}}$ & $11,55 \pm 20,01^{\mathrm{ab}}$ \\
\hline DC & $6,43 \pm 2,19^{\mathrm{bc}}$ & $4,51 \pm 1,02^{\mathrm{abc}}$ & $5,12 \pm 0,86^{\mathrm{ab}}$ & $1,95 \pm 1,22^{\mathrm{abc}}$ & $1,92 \pm 0,97^{\mathrm{a}}$ & $1,10 \pm 0,96^{\mathrm{a}}$ & $2,11 \pm 1,36^{\mathrm{a}}$ & $2,10 \pm 1,39^{\mathrm{a}}$ \\
\hline
\end{tabular}

Different superscript letters in the same column represent significant differences at the level of $\mathrm{P}<0.05$.

${ }^{\mathrm{b}}$ Extract Ethanol 25\%, 50\%, and 75\% (E25, E50, E75, respectively), Extract Aquades (EA), Drug Control (DC).

${ }^{\mathrm{c}}$ Extract consisted of three doses: 200,400 and $800 \mathrm{mg} / \mathrm{kg} \mathrm{BW}$ 
The presence of parasites after treatment can be caused by the presence of a schizont stage from Plasmodium which is still found in the tissues, for example in the liver [9]. The stage is not visible in the blood circulation so the percentage of parasitemia cannot be calculated. To prove that there are still Plasmodium parasites in the liver histopathological examination will be done. In addition, there may be other factors that can cause parasites after treatment, namely the activity of cytochrome $\mathrm{P} 450$ isoenzymes, CYP2D6 [10,11,12].

\section{Conclusion}

The results showed that the percentage of parasitemia was still found in all treatments due to infection with $P$. berghei and after 4 days of treatment with $S$. ligustrina extract and drugs. Based on these results it is recommended for further research that administration of S. ligustrina extract and DHP drugs as antimalarial drugs for more than four days.

\section{Acknowledgments}

Thank you to RISTEKDIKTI who provided research funding under the title: Making antimalarial drugs made from sea Bidara wood extract (Strychnos ligustrina), with contract number: 4223/IT1.11/PN/2019.

\section{References}

1. Taylor MA, Coop RL, Wall RL: Veterinary Parasitology Third Edition. Oxford (UK): Blackwell Publishing. 2007.

2. Raini M, Gitawati R, Isnawati A, et al.: Keluhan dan Kepatuhan Penderita malaria Terhadap Pengobatan Malaria Artesunat-Amodiakuin di kalimantan dan Sulawesi. Media Penelitian dan Pengembangan Kesehatan. 2011;21(3):111-118.
3. Noedl H, Socheat D, Satimai W: Artemisinin-Resistant malaria in Asia. $N$ Engl $J$, 2009;361(5): 540-541.

4. Frederich M, Hayette MP, Tits M, et al.: In vitro activities of Strychnos alkaloids and extract against Plasmodium falciparum. Antimicrob. Agents Chemother. 1999;43(9): 2328-2331.

5. Syafii W, Sari RK, Cahyaningsih U, et al:: Antimalarial Activity of Bidara laut Wood Extract. Jurnal Ilmu Teknologi kayu Tropis. 2016;14(1): 1-10.

6. Basir R, Fazalul Rahiman SS, Hasballah K: et al.: Plasmodium berghei. ANKA infection in ICR mice as a model of cerebral malaria. Iran J Parasitol. 2012; 7(4):62-74.

7. Yusuf Y: Faktor resiko munculnya Plasmodium spp resisten di Kecamatan Tapalang, Sulawesi Barat. Jurnal Bionature. 2014;15(1): 41-44.

8. Hasugian AR, Risniati Y, Tjitra E, et al.: Efikasi dan Keamanan Dihidroartemisinin - Piperakuin Pada Penderita Plasmodium vivax di Kalimantan dan Sulawesi. Media Litbang Kesehatan. 2012;22(2):78-86.

9. Azlin E: Obat anti malaria. Sari Pediatri. 2004;5(4): 150154 .

10. Layal K, Gayatri A: Pengaruh CYP2D6 terhadap Kegagalan Terapi Primakuin pada Malaria Vivaks. Syifa Medika. 2014;4(1): 1-15.

11. Daher A, Yulio C, Silva L, et al.: Evaluation of P.vivax malaria recurrence in Brazil. Malar J. 2019;18:18.

12. Brasil LW, Soares FR, Santoro AB, Et al:: CYP2D6 activity and risk of recurrence of $P$. vivax malaria in Brazilian Amazon: a prospective cohort study. Malar J. 2018;17:57. 